\title{
Lâminas de Corte: sobre três estratégias para o encontro com o "humano"I
}

\author{
[ Cutting Blades: about three strategies to find the "human"
}

\section{Roberto Efrem Filho}

RESUmo Tomando como objeto de análise a peça teatral $O$ Deus da Fortuna (uma parábola sobre a metafísica do capital), este ensaio procura compreender as intenções políticas e a narrativa dramatúrgica do espetáculo como uma oportunidade de olhar para as representações das relações sociais em que o Coletivo de Teatro Alfenim, autor da peça, intervém artisticamente. Este ensaio discute tais intervenções como estratégias de encontro com o "humano", problematizando a noção de "humanidade" e explicitando as relações de classe, gênero e sexualidade nas quais os sujeitos criam, fazem-se e conjugam seus verbos - PalaVRas-ChaVe humanização; Coletivo de Teatro Alfenin; relações de classe, gênero e sexualidade. - ABSTRACT Taking as an object of analysis the play The God of Fortune (a parable about the metaphysics of capital), this essay seeks to understand the political intentions and the dramaturgical narrative of the play as an opportunity to look at the representations of the social relations in which the Alfenim Collective, author of the play, acts artistically. This essay discusses such actions as strategies for meeting the "human", questioning the notion of "humanity" and explaining the relations of class, gender and sexuality in which individuals create, make themselves and conjugate their verbs - KEYwords humanization; Coletivo de Teatro Alfenin; class, gender and sexuality relations.

Recebido em 23 de outubro de 2014

Aprovado em 23 de outubro de 2014

EFREM FILHO, Roberto. Lâminas de Corte: sobre três estratégias para o encontro com o "humano". Revista do Instituto de Estudos Brasileiros, Brasil, n. 6o, p. I52-I70, abr. 2015.

DoI: http://dx.doi.org/Io.II606/issn.23I6-90IX.voi6opI52-I70

I Agradeço ao Coletivo de Teatro Alfenim pela possibilidade de escrever sobre uma de suas obras e de participar, ainda que minimamente, de seu processo criativo. Agradeço a Irandhir Santos pela leitura carinhosa deste texto e por seus valiosos comentários. Como explicado no corpo deste trabalho, uma primeira e bastante diminuta discussão acerca dos temas aqui tratados foi publicada no Caderno de Apontamentos de O Deus da Fortuna.

2 Universidade Federal da Paraíba (UFPB, João Pessoa, PB, Brasil). 
Talvez as mais importantes contribuições intelectuais à compreensão da realidade em que um tempo se refaz (e que por ele é refeita) sejam aquelas tão maleáveis quanto afiadas. São interpretações do mundo capazes de penetrar as mais ermas searas, os mais intricados espaços, contorcendo-se, se necessário, reinventando-se. Walter Benjamin foi autor de contribuições assim. Enquanto os intelectuais de seu tempo definhavam desesperançosos diante do terror da sociedade capitalista que eles desvendavam - e que, de fato, era bastante assustadora, com seus nazismos, esteiras produtivas e surras no Pato Donald ${ }^{3}$ - Benjamin transitava com lâminas nesses terrenos cruéis. Lá, entre todas as tiranias, com gestos de coragem e ousadia, ele alcançava o espaço-tempo em que os oprimidos, apesar de tudo o que os nega e por isso mesmo, afirmam-se e nos permitem alguma esperança.

Foi desse modo, por exemplo, que Benjamin chegou à questão do trabalho do ator frente à câmera. Nos interstícios da indústria cultural, exatamente no momento em que a classe trabalhadora se fecha em uma sala escura com uma tela branca, Benjamin delineou o ato dramático de uma vingança. Ali, nos anos $30 \mathrm{ou}$ 40 do século XX, no interior do cinema, cansados de suas jornadas de trabalho exaustivas, desejando (ser) o mocinho ou (ser) a mocinha, homens e mulheres da classe trabalhadora se deparam com o trabalho de outro sujeito, o ator, aquele que representa. Este sujeito que representa, tal quais os trabalhadores que a ele assistem, atua perante uma máquina, um aparelho. Ele não conhece o público, não o enxerga. $\mathrm{O}$ ator vê apenas o aparelho, esforça-se para o aparelho, sorri e chora para o aparelho e é através dele, atendendo às exigências do microfone e das luzes dos refletores, que o ator afirma sua humanidade. Aqui, a vingança se perfaz. No instante em que, na sala escura, quando já não se vê a câmera - uma máquina, como são as máquinas frente às quais "os citadinos precisam alienar-se de sua humanidade, nos balcões e nas fábricas, durante o dia do trabalho"4 - o ator se vinga do aparelho, colocando-o a serviço do seu próprio triunfo. $\mathrm{O}$ aparelho desaparece, o ator age, lâminas cintilam.

3 O "Pato Donald" é uma referência ao que Adorno e Horkheimer chamaram, em seus trabalhos, de "indústria cultural”. Nela, as surras no Pato constituíam mais uma das formas de acomodação dos espectadores às surras cotidianas a eles destinadas pela sociedade capitalista. Ver, especialmente: ADORNO, Theodor. Indústria Cultural e Sociedade. Seleção de textos: Jorge Mattos Brito de Almeida. Trad. de Julia Elisabeth Levy, Jorge Mattos Brito de Almeida e Maria Helena Ruschel. 3. ed. São Paulo, Paz e Terra, 2006. 4 BENJAMIN, Walter. A Obra de Arte na Era de Sua Reprodutibilidade Técnica. In: . Magia e Técnica, 
O Coletivo de Teatro Alfenim é autor de contribuições assim. Nascido no ano de 2007 na cidade de João Pessoa, o Coletivo segue hoje, em outubro de 20I4, para o seu sexto espetáculo. Desde a sua estreia com a peça Quebra-Quilos, em 2008, o Alfenim experimenta criações de obras autorais através do exercício da "dramaturgia em processo”. Com essa opção metodológica, o grupo oportuniza que os textos de suas montagens emirjam da sala de ensaios a partir dos esforços de seus integrantes. Mas esses esforços operam um conjunto criativo decidido a não compactuar com quaisquer noções abstracionistas de "público", aquilo que Benjamin chamou de "falsa e mistificadora totalidade”. Muito pelo contrário, talvez mesmo ao avesso, o Coletivo de Teatro Alfenim rejeita genericidades e toma posições políticas explícitas numa conjuntura histórica avessa à sua existência, em que cultura e mercado se relacionam simbioticamente, em que, como escreveu Fredric Jameson ${ }^{6}$, a cultura se converte numa arena catalisadora de expansão do capital. O Coletivo desfere golpes cortantes sobre a realidade em que se acha implicado. Sua escolha de caminhar com Brecht - e caminhar com Marx e com os sujeitos cujas lutas restauram aquelas esperanças - e de demolir as quartas paredes, que em círculos de conforto nos domesticam, assinala um compromisso evidente que é maior com a arte ao passo que é mais intenso com as classes e grupos sociais subalternizados.

Em verdade, quer queiram, quer não, os cortes realizados pelo Coletivo sangram o corpo do próprio campo artístico, dos seus pudores em "se perder na política”, em "substituir a cena pelo protesto". Se o Coletivo opta por uma arte engajada, dedica-se, sobretudo, ao exercício de uma metodologia criativa habilmente pedagógica, dialógica, do gosto mesmo com que Paulo Freire ${ }^{7}$ experimentou a palavra "libertação". Sua "dramaturgia em processo", politicamente orientada, recepciona plateias diversas. $\mathrm{O}$ "público" mais acostumado ao desconforto das cadeiras dos melhores teatros - e os melhores teatros são aqueles desconfortantes ${ }^{8}$ - senta-se nas mesmas

Arte e Política: Ensaios Sobre Literatura e História da Cultura. Obras Escolhidas, v. I. Trad. de Sérgio Paulo Rouanet. 7, ed., II. reimpr. São Paulo, Brasiliense, 20II, p. I79.

5 BENJAMIN, Walter. Que é o Teatro Épico? Um Estudo sobre Brecht. In: Magia e Técnica, Arte e Política: Ensaios sobre Literatura e História da Cultura. Obras Escolhidas, v. I. Trad. de Sérgio Paulo Rouanet. 7. ed., II. reimpr. São Paulo, Brasiliense, 20II, p. 86.

6 JAMESON, Fredric. A Virada Cultural: Reflexões sobre o Pós-moderno. Trad. de Carolina Araújo. Rio de Janeiro, Civilização Brasileira, 2006.

7 FREIRE, Paulo. Pedagogia do Oprimido. 36. ed. São Paulo, Paz e Terra, 2003.

8 Refiro-me ao ranger das cadeiras do teatro de que falava Oduvaldo Vianna Filho quando de sua atuação em Liberdade, Liberdade, espetáculo imprescindível da dramaturgia brasileira dirigido por Flávio Rangel e Millôr Fernandes e estreado em 2I de abril de I965. Vianna dizia: “E aqui, antes de continuar este espetáculo, é necessário que façamos uma advertência a todos e a cada um. Neste momento, achamos fundamental que cada um tome uma posição definida. Sem que cada uma tome uma posição definida, não é possível continuarmos. É fundamental que cada um tome uma posição, seja para a esquerda, seja para a direita. Admitimos mesmo que alguns tomem uma posição neutra, fiquem de braços cruzados. Mas é preciso que cada um, uma vez tomada sua posição, fique nela! Porque senão, companheiros, as cadeiras do teatro rangem muito e ninguém ouve nada". Os editores do texto da peça teatral esclarecem: "Trecho introduzido no espetáculo no dia da estréia, a pedido do arquiteto Lúcio Costa que, tendo assistido ao ensaio geral, sugeriu 
arquibancadas ocupadas por integrantes de movimentos sociais, trabalhadores sem terra, feministas e estudantes. Uns e outros compartilham o espaço cênico instaurado pelo Coletivo de Teatro Alfenim. Nele, longe de pretender "educar" as classes subalternas para o trânsito dócil nas artes burguesas, o Coletivo "deseduca" a sociedade. Desfaz-se de maquinarias e afirma a humanidade do ator no impacto frontal com a humanidade do público.

A tarefa a que o Coletivo se obriga, entretanto, parece ainda mais árdua do que aquela do ator descrito por Benjamin. A vingança provocada pelo ator benjaminiano vinha reivindicar, ironicamente, sua humanidade perante o aparelho, mas isso num mundo em que a noção de "humano" guardava maior sentido. Não porque as pessoas ou instituições daquele contexto fossem "mais humanas" do que as atuais. (O emprego do "humano" como um valor essencialista mistifica sua arquitetura histórica, o fato mesmo de que ser humano não tem nada a ver com ter nascido homo sapiens e sim com os preços a serem pagos para ser mais, ser menos ou sequer ser "humano"?.) Mas porque, à época de Benjamin, o "humano" pretendia-se universalizado pelos discursos liberais então dominantes, segundo uma concepção de sociedade marcada pela liberdade, pela igualdade e pela fraternidade. Por certo, tal concepção demonstrou sua fragilidade retórica e seu substrato material na guinada (inesperada?) de algumas nações ocidentais ao nazismo e ao fascismo. Até aí, porém, no enfrentamento a essas ideologias tão capitalistas quanto o próprio liberalismo, o "humano" emergia. Agora como integrante de todo um arsenal simbólico contrário às atrocidades perpetradas pelos regimes totalitários. Esse "humano", contudo, moldado à imagem e à semelhança do humano burguês, proprietário, livre para o exercício de direitos, sujeito para conjugar todos os verbos possíveis sob o "contrato social", (ir)realizava-se mais materialmente em humanos para quem a única liberdade real estava em vender sua força de trabalho, submeter-se à geração da mais-valia e frustrar-se pela impossibilidade fática de se aproximar do "humano" que lhes diziam ser. Eram esses humanos que se sentavam frente à tela em que o ator triunfava e reivindicava, contra a máquina, sua humanidade. São esses humanos que o atual estágio do modo de produção capitalista quer, a todo custo, negar.

A tarefa do Coletivo de Teatro Alfenim é mais árdua porque há cada vez menos "humanidade" sobre as superfícies a reivindicar - ainda que as pessoas cujas vidas são dedicadas ao trabalho continuem a existir, como sempre existiram, ainda que permaneçam imersas em "sonos profundos de inconsciência de classe", como nota o próprio Coletivo, ainda que se mantenham engendrando mais-valia e sofrendo da exploração inexorável à contradição entre capital e trabalho. A tarefa do Coletivo é mais árdua porque novos subterrâneos precisam ser cortados sob as primeiras camadas do capitalismo financeiro. Porque o humano, espoliado nos meandros das conexões entre as bolsas de valores, as ações bancárias e o capital internacional,

aos autores que fizessem alguma coisa com referência ao lamentável barulho das cadeiras do teatro. Não podendo apelar para a engenharia, os autores apelaram para o humor". RANGEL, Flávio \& FERNANDES, Millôr. Liberdade, Liberdade. 5. ed. São Paulo, L\&PM, I987, p. 3I-32.

9 Jorge Furtado, em seu documentário Ilha das Flores, vale-se de uma linguagem avassaladora para demonstrar que portar um telencéfalo desenvolvido e polegares opositores não faz de ninguém "humano". 
requer escafandristas para ser encontrado nas Chinas que as novas configurações da divisão internacional do trabalho impõem. E o Coletivo de Teatro Alfenim cumpre com essa tarefa. O Deus da Fortuna (uma Parábola sobre a Metafísica do Capital), o espetáculo teatral do Coletivo Alfenim de que me valho como referência para este texto, constitui um avanço em territórios que as artes cênicas, pisando sobre eles como quem engatinha em campos minados, costumam desconhecer ou evitar.

Meu primeiro contato com $O$ Deus da Fortuna se deu há três anos, em outubro de 20II. Ãquela época, como ainda hoje acontece, minhas aulas na Universidade Federal da Paraíba se somavam ao trabalho de orientação de estudantes pertencentes ao Núcleo de Extensão Popular Flor de Mandacaru (NEP) ${ }^{\text {ro }}$, e à participação frequente em atividades e eventos empreendidos por movimentos sociais, especialmente da Paraíba e de Pernambuco. Em meio às aulas, oficinas e reuniões, recebi uma mensagem eletrônica enviada por Gabriela Arruda, produtora do Coletivo. O Alfenim então se desdobrava na criação de seu novo espetáculo. Por isso, organizava um seminário aberto a quaisquer interessados acerca das temáticas fundamentais para a construção da peça e que, além de contribuir com as pesquisas do grupo na tessitura do texto, visava ao que se costuma chamar de "formação de plateias". A mensagem de Gabriela me convidava para, na companhia do professor Romero Venâncio, compor uma das mesas do seminário. Nossa tarefa seria a de debater com os membros do Coletivo e as demais pessoas ali presentes as relações entre o atual estágio do modo de produção capitalista, a "religião" e a "metafísica do capital".

Muito mais honrado com a proposta do que habilitado intelectualmente para a execução da tarefa requerida, eu aceitei o convite um tanto irresponsavelmente. Eu conhecia a obra do Coletivo de Teatro Alfenim há alguns anos, desde que assisti, surpreendido, a Quebra-Quilos numa das “desconfortantes" arquibancadas do Teatro Hermilo Borba Filho, no Recife. O convite realizado por Gabriela me punha mais uma vez em contato com um trabalho que eu admirava enormemente como espectador e militante entusiasmado, mas cujas arquiteturas dramatúrgicas e cênicas eu jamais seria capaz de acessar em seus detalhes. Nunca fui um estudioso ou conhecedor das artes cênicas e, de certo, não preenchia os requisitos para a “crítica teatral”. Entretanto, sob os riscos das irresponsabilidades, valendo-me do pouco arsenal teórico e político que eu arregimentava, participei (deslumbrado) da mesa. Tendo aprendido muito mais do que ensinado, e já depois de assistir ao espetáculo algumas vezes, escrevi, em resposta a um segundo convite do Coletivo, um texto a respeito das discussões

Io O NEP consiste num coletivo auto-organizado de estudantes que, desde 2007, desenvolve atividades de assessoria jurídica universitária popular junto a diversos movimentos sociais na Paraíba. Ele conta com a colaboração de alguns professores que respondem pelos projetos do Núcleo frente à administração da UFPB e auxiliam nos processos de formação e orientação dos estudantes e no diálogo com os movimentos. Renata Ribeiro Rolim, Ana Lia Almeida e eu - embora outros docentes já tenham ocupado algumas dessas funções anteriormente - somos os professores mais próximos do Núcleo e, formalmente, seus “coordenadores”. 
travadas durante o seminário e sobre $O$ Deus da Fortuna. Aquele texto juntar-se-ia a outras reflexões sobre a peça e a trabalhos de outros participantes do seminário no Caderno de Apontamentos do espetáculo. Três anos depois, contudo, a partir daquele texto, este texto que agora apresento se desenlaça, perfilhando algumas das análises e linhas já ali anunciadas e correndo os riscos das mesmas irresponsabilidades.

Aqui, entretanto, O Deus da Fortuna, suas intenções políticas e sua narrativa dramatúrgica se convertem numa oportunidade para um olhar para as representações das relações sociais em que o Coletivo de Teatro Alfenim intervém artisticamente. A escrita deste trabalho se alimenta, intuitivamente, da análise do texto da peça e dos registros das vezes em que assisti ao espetáculo no prédio da Casa de Cultura Cia. da Terra, no Centro Histórico de João Pessoa. Trata-se, como se vê, de um trabalho ensaístico. Sua estética, a do ensaio, permite que eu me movimente por meio de análises sem maiores rigores metodológicos. Como disse anteriormente, nestas páginas o teatro se transforma numa "oportunidade" - mas espero sinceramente não incorrer em “oportunismos". Lido, neste ensaio, com apenas algumas das temáticas que O Deus da Fortuna comove e, por determinadas escolhas, talvez eu termine deixando quietos outros assuntos presentes na peça teatral e que uma análise mais séria não poderia evitar. Ainda assim, arrisco-me com este texto por acreditar que o teatro pode oferecer às análises dos conflitos sociais e às próprias lutas sociais mecanismos cortantes, maleáveis e afiados de compreensão, construção e disputa da realidade. Enfim, se apesar de todas essas minhas "desculpas", a este ensaio ainda couber a acusação de "amadorismo intelectual", eu sempre poderei acionar retoricamente a estratégia brechtiana talhada por Walter Benjamin e por suas lâminas:

Nada é mais característico do pensamento de Brecht que a tentativa do teatro épico de transformar, de modo imediato, esse interesse originário num interesse de especialista. O teatro épico se dirige a indivíduos interessados, que "não pensam sem motivo". Mas essa é uma atitude que eles partilham com as massas. No esforço de interessar essas massas pelo teatro, como especialistas, e não através da “cultura”, o materialismo histórico de Brecht se afirma inequivocamente. "Desse modo, teríamos muito breve um teatro cheio de especialistas, da mesma forma que um estádio esportivo está cheio de especialistas". ${ }^{\text {II }}$

\section{FAZENDO-SE "TIGRE" ENTRE AS AMBIGUIDADES DO "HUMANO"}

O Deus da Fortuna (uma Parábola sobre a Metafísica do Capital) é o quarto espetáculo do Coletivo de Teatro Alfenim. Resultado de um esforço coletivo de pesquisa, o espetáculo conta com texto, direção, cenário e iluminação de Márcio Marciano; atuações de Adriano Cabral, Lara Torrezan, Mayra Ferreira, Nuriey Castro, Paula Coelho, Ricardo Canella, Suellen Brito e Vitor Blam; direção de arte e figurinos de Vilmara Georgina; direção musical de Mayra Ferreira e Nuriey Castro; composições

II BENJAMIN, Walter. Que é o Teatro Épico?..., op. cit., p. 8I. 
musicais de Wilame A. C. e do Coletivo Alfenim; projeto gráfico de Marcello Tostes; produção executiva de Gabriela Arruda; e realização do próprio Coletivo de Teatro Alfenim. $\mathrm{O}$ argumento central do espetáculo se aproveita de um fragmento dos diários de Bertolt Brecht acerca da figura de Zhao Gongming, o próprio Deus da Fortuna $^{\mathrm{I}}$. De acordo com os escritos de Brecht, à época da elevação da Grande Muralha da China, o Deus da Fortuna resolveu viajar pelo continente. Seus caminhos, no entanto, deixavam marcas de violência e assassínio. $O$ deus viajante foi então denunciado, julgado e condenado, mas no momento da execução da pena de morte, revelou-se que o deus gozava de imortalidade. Carrascos e sacerdotes restaram aturdidos e, exaustos, desistiram da morte de Zhao Gongming. "Lá fora, a multidão que, temerosa, viera assistir à execução, retirou-se cheia de renovada esperança...” ${ }^{\text {I3 }}$ Apreendendo as intenções de Brecht de escrever uma peça teatral inspirada na figura do Deus da Fortuna, nos interstícios entre a imortalidade divina e a "esperança" da multidão, o Coletivo de Teatro Alfenim estrutura a sua parábola.

Nela, o Senhor Wang, um proprietário de extensas terras e arrozais, encontra-se falido em razão da perda do valor comercial do arroz. Suas dívidas infindáveis comprometem suas propriedades e seu status. Nem a imagem do Deus da Fortuna existente na sala de sua casa, onde vive com a filha e com empregados, ajuda na superação da falência. Nenhuma riqueza chega às mãos do Senhor Wang que já não multiplique, em sua chegada, novas dívidas: os empréstimos tomados junto a Cai Fu, um agiota, concentram parte significativa dos débitos do proprietário, mantendo-o preso a um círculo vicioso. Pensando em eliminar as dívidas com o agiota, o Senhor Wang resolve negociar sua filha, Jin-Jing, em casamento com Shang, filho de Cai Fu. Indócil, Jin-Jing recusa a obrigação do casamento arranjado pelo pai e ameaça o suicídio. Jogar-se-ia no lago da propriedade e morreria afogada, tal qual sua mãe fez um dia. Enquanto as empregadas da casa, a Senhora Shu e a Senhora Liu Po, mais velha e mais nova respectivamente, tentam demover Jin-Jing da ideia do suicídio e convencê-la das possibilidades de um casamento - como veremos, algo desprovido de quaisquer pretensões de "amor" - aquele círculo vicioso se aperta, diminuindo seu diâmetro ao redor do Senhor Wang. O proprietário procura então o agiota e Cai Fu assevera que à noite, na casa do Senhor Wang, um novo contrato seria celebrado, o contrato do casamento entre Jin-Jing e Shang.

De volta à sua casa, contudo, o Senhor Wang é alertado por um de seus empregados, o Secretário Koo, de que os colonos (moradores e trabalhadores) da propriedade cruzaram os braços e dizem se negar a voltar ao trabalho até que recebam as provisões

I2 Utilizo o próprio texto do espetáculo para reconstruir narrativamente o fragmento dos diários brechtianos de que partiram os esforços criativos do Coletivo de Teatro Alfenim. Agradeço a Gabriela Arruda, produtora do Coletivo, e ao Coletivo pela disponibilização do texto e pela permissão para que eu fizesse referências e citações a ele neste trabalho.

I3 Emprego aspas para as citações diretas ao texto dramatúrgico de O Deus da Fortuna. Sendo assim, todos os excertos do texto aqui citados diretamente se acham aspados, ainda que não contem com indicação de paginação ou referências bibliográficas formais. Como o texto do espetáculo ainda não foi publicado e, portanto, não pode ser acessado por quem lê este ensaio, penso não haver sentido em mencionar as páginas de que retiro as citações. 
do mês. Mas o proprietário desdenha da movimentação dos trabalhadores e mesmo quando um grupo de colonos vem gritar à sua porta, o Senhor Wang brada que não pagará as provisões e, irritadiço, manda-os “lamber o cu das vacas”. Resignados, os trabalhadores se vão e o proprietário, sua filha e seus empregados permanecem (se) preparando (para) o banquete do casamento. Um pato degolado, depenado, escaldado e estripado, mas temperado, gengibrado e apimentado pelos orifícios será servido à mesa. Até lá, a noite se espraia pela casa senhorial. Cai Fu e Shang chegam à casa e, na companhia do Senhor Wang, refestelam-se com o banquete. Após Jin-Jing executar (ou chorar) uma dança para os convidados e voltar de uma conversa com Chang na varanda da casa, Cai Fu elogia o pato - "sublime" - e se opondo à insistência do Senhor Wang em continuar com o vinho, anuncia que é tarde, o dia já amanhece, e ele, o filho e a esposa do filho devem se retirar. O Senhor Wang, no entanto, argumenta que antes de levarem a sua filha à consumação do contrato de núpcias, os papéis de suas dívidas com o agiota precisariam ser rasgados. Mas Cai Fu se recusa. "- Jin-Jing só sairá desta casa depois que minhas dívidas forem honradas." "- A honra de sua filha não pagará suas dívidas." Os dois brigam, ofendem-se e depois de a Senhora Shu intervir pacificadoramente, eles voltam a conversar.

Em meio à conversa e a mais um pedido de crédito ao agiota, o Senhor Wang, desiludido, perjura contra o Deus da Fortuna: "-É um impostor. Oferece ao crédulo a ilusão de que a felicidade é um bem para todos. Mas o que vemos é só miséria e desolação". Cai Fu então questiona se o próprio Wang não representa um desses sujeitos para quem, à exceção da maioria, a felicidade é oferecida. O Senhor Wang nega. Os seus inesgotáveis endividamentos não o permitiriam representar. Em resposta, o agiota promove uma reviravolta na contenda e se apresenta como sendo, ele mesmo, o Deus da Fortuna. Em cena, o ator é "homem” (agiota...) e deus a um só tempo. Incerto se está tomado pelo excesso de vinho ou pelos poderes divinos do refeito Cai Fu, o Senhor Wang é preso, amordaçado e conduzido pelo Deus da Fortuna a julgamento. $\mathrm{O}$ julgador convocado pelo deus é o colono que liderava a insurreição. Apesar de instigado pelo Deus da Fortuna a condenar o proprietário, o colono rejeita as acusações de tirania, inimizade e exploração contra o seu senhor. "-Ele é um bom patrão." O trabalhador então se define como pessoa simples, incapaz de acusar quem lhe concede abrigo e comida, desculpando o Senhor Wang em razão de ser ele "um bom homem". Insatisfeito, o Deus da Fortuna rememora o colono da violência com que o Senhor Wang trata os seus subordinados, das humilhações e das corrupções. O colono, porém, sem ser dissuadido, reitera: "—É um ser humano".

Como seu último recurso para a condenação do réu, o Deus da Fortuna conclama à palavra um "Coro de Colonos Adormecidos", despertando-os temporariamente do "sono da ignorância". O coro se apresenta e alcança o ápice pedagógico do espetáculo: "Se não estivéssemos dormindo o sono dos injustiçados, bovinamente acomodados na crença dos valores eternos, eis o que diríamos: morte aos canalhas proprietários!; morte aos espoliadores do trabalho!; morte aos especuladores bandoleiros!; criaremos um novo mundo!". Os colonos despertos lançam esperanças à plateia - "acordaremos" e voltam a dormir. Por fim, o Deus da Fortuna requisita ao colono julgador o veredicto. O colono, entretanto, esquiva-se e, sem haver sabido que se deparara com o próprio Deus, absolve o seu senhor: "— Não cabe a nós a decisão. Seja paciente, o Deus da 
Fortuna baterá à nossa porta”. Inocentado, o Senhor Wang afugenta os trabalhadores e revela ao Mestre Cai Fu que sofrera uma revelação. Nela, o agiota era o Deus da Fortuna encarnado. O Senhor Wang conclui: "—Será uma benção pertencer à sua casa”.

A primeira estratégia de encontro com o "humano" que O Deus da Fortuna proporciona consiste num aparente desencontro. $\mathrm{O}$ argumento brechtiano que lastreia o espetáculo se concentra, como dito, na imagem de um deus, aquele dentre as personagens que não é humano, que não padece da possibilidade da história ou da morte, ao menos não da sua. Mas, mais que isso, o encontro com deus - o desumanizado - consiste num aparente desencontro porque termina por fabricar uma humanidade indistinta em oposição ao deus encontrado. Jin-Jing e Liu Po, a filha do patrão e a criada, rezam juntas perante a imagem da mesma divindade. Diante de deus, afinal, todos somos "humanos". É contra essa indistinção pressuposta que o Coletivo Alfenim atua redesenhando em cena as relações de poder que disputam os sentidos do humano. De antemão, ainda no prólogo da peça, um deus reconhece (metafisicamente?) encarnar o capital e decide se fazer homem. Desafia então um tigre, encarnação do trabalho, a fazer o mesmo. Mas o tigre, um felino inconsolável mantido entre as pernas do deus, ressente-se por ter de se fazer humano mais uma vez. Inaugura-se, a partir daí, um jogo cênico formado por um deus que se fez homem em busca de comprovações ${ }^{14} \mathrm{e} u m$ tigre, feito homem, convencido da perda da batalha. Em meio aos dois, as diferentes personagens antes mencionadas conduzem a comédia e, seguindo didaticamente as lições brechtianas, introduzem no cenário uma série de metáforas de concepções marxianas. O fetiche religioso, o fetiche da mercadoria, a luta de classes, as formas de propriedade, o dinheiro: de uma gargalhada à outra do público, os conceitos penetram pouco a pouco a cena.

Mas as humanizações em questão são de naturezas diferentes. Enquanto a humanidade do deus humanizado agiota se torna inquestionável frente às demais personagens da parábola, a humanidade do tigre humanizado colono nada tem de óbvia. Quando pressionado pelo Mestre Cai Fu em razão das suas dívidas, o Senhor Wang não vacila: "- Mas será possível? Empenho as vacas, as galinhas, os colonos". E Cai Fu, deus que é, sequer se incomoda com a animalização ou a proprietarização dos trabalhadores: "- Tudo já foi devidamente empenhado". No entanto, as ambiguidades das humanizações ou desumanizações não cessam por aí. Elas se exprimem, forjadas em relações de gênero e sexualidade, na figura da filha do patrão. Ao se deparar com assombrações do seu passado, o Senhor Wang é interpelado pela Senhora Wang, sua esposa suicida, mãe morta de Jin-Jing: "— Não venda sua filha como a um saco de batatas!". Ele retruca: "— Nunca cometerei tamanha indignidade! Minha filha vale uma boa dúzia de vacas".

O próprio Senhor Wang, porém, personifica melhor do que ninguém aquelas ambiguidades. O Deus da Fortuna leva-o a julgamento, põe-no de joelhos, prende seus braços e pernas a bastões, amordaça a sua boca. Os colonos, todavia, reverenciam-no como um deus, um "paizinho", uma autoridade inconteste, sobretudo quando contestada. O colono julgador recusa-se a julgá-lo e a condená-lo, mas justifica a

I4 A propósito, as formulações cristãs conheceriam alegorias desse gênero? 
absolvição em razão do "bom patrão", do "bom homem", do "ser humano" que ele é. Claro, Cai Fu e Senhor Wang servem de metáfora para a relação entre o capital financeiro e formas mais tradicionais de propriedade privada. Há, sendo assim, um conflito, uma desarmonia entre as duas personagens. O Deus da Fortuna define o proprietário como sendo "um primitivo acumulador de dinheiro; um primitivo espoliador de trabalho" e, distinguindo-se do Senhor Wang, autoelogia o "verdadeiro poder" de sua "imaterial presença". Sua imaterialidade contrasta, portanto, com a materialidade menor do dono de arrozais. A personagem imaterial do deus é a narradora total do espetáculo. Ela desfruta de onipresença, onipotência e onisciência cênicas. O deus nunca é surpreendido. Assume o ponto de vista particular do Mestre Cai Fu, o agiota, apenas para manter um silêncio arrogante e desdenhoso, demarcado por falas curtas e secas, contra a fanfarronice, as ilações retóricas e as bravatas do Senhor Wang. O deus exprime a "metafísica do capital".

Entretanto, a despeito de sua imaterial superioridade, falta ao capital financeiro a disposição ou a coragem para ser, ele propriamente, o julgado. Na realização do desafio que o Deus da Fortuna desfere sobre o tigre que mantinha entre suas pernas, o Deus não se arrisca em confrontar o colono insurreto durante o julgamento. Como dito, é o Senhor Wang o julgado. Numa sorrateira disputa com o proprietário e na intenção de justificar a posição de réu imposta a Wang, o Deus da Fortuna interroga: "—Quem reina poderoso nesta propriedade?"; "- Quem tem o poder sobre a vida e a morte dos empregados?"; "- Quem é o senhor soberano de toda fortuna destas terras?". Constrangido pelo deus, o Senhor Wang responde afirmativamente e assume sua responsabilidade a cada uma das perguntas. Contudo, a última resposta do Senhor Wang emblematiza a disputa - que ele perde - acerca da legitimidade para a ocupação da posição passiva no julgamento. Perguntado quem é o senhor soberano da fortuna daquelas terras, o Senhor Wang responde: "- Mais uma vez a resposta é Wang, o senhor da fortuna, com a permissão de meu sereníssimo credor Mestre Cai Fu".

Esta provocação permissiva do proprietário não recebe atenção explícita do Deus da Fortuna, mas expõe a raison d'être do desenlace de um julgamento contra o proprietário e não contra o Deus: a inescapável materialidade do humano. De fato, só haveria sentido em empreender um julgamento contra alguém condenável e executável. Não seria este o caso de um deus. Mas, além disso, só sobreviria sentido em julgar, condenar e executar um "humano", ou seja, um sujeito materialmente implicado no conflito que oportuniza a contenda. Sem esse sujeito "humano", a imaterialidade do Deus da Fortuna ou do capital financeiro não encontraria lastro nas condições materiais de existência, não resistiria. Sendo assim, a "imaterialidade divina" é devedora insolvente das "materialidades humanas" sempre "materializações humanas", consideradas as disputas sobre a construção ou a desconstrução do "humano". É exatamente por isso que, ao promover o julgamento do Senhor Wang e se subtrair do julgamento de si, o Deus da Fortuna recorre inexoravelmente ao julgamento do tigre, do colono. $\mathrm{O}$ alvo central do julgamento final, isto está prenunciado desde o início do espetáculo, é o trabalhador e não o Senhor Wang. O trabalhador constitui o tigre parabólico desafiado pelo deus. Como nas noções marxianas mais fundamentais, a experiência do trabalho engendra a riqueza patronal e, destarte, produz a imaterialidade com que se regozija o capital 
financeiro. Não há ingenuidades em O Deus da Fortuna. As opções restam bastante claras: o deus é a negação do tigre, o tigre é a negação do deus. Para o deus não ser julgado, o tigre o é. Este humano julgado (e, ao menos até este momento da história, condenado) representa o sujeito que o Coletivo de Teatro Alfenim se movimenta para desvendar, construir, disputar.

No entanto, o Coletivo não adentra essa disputa como o faria o "intelectual" que se pretende meramente ao lado da classe trabalhadora. O Alfenim não intenciona ocupar "o lugar de um protetor, de um mecenas ideológico" ㄷ. Pelo contrário, assim como percebeu Walter Benjamin, o Coletivo de Teatro Alfenim compreende que "o lugar do intelectual na luta de classes só pode ser determinado, ou escolhido, em função de sua posição no processo produtivo" ${ }^{\text {I6 }}$. (No primeiro andar do prédio da Casa de Cultura Cia. da Terra, no Centro Histórico de João Pessoa, eu me deparei frontalmente com trabalhadores da cena, trabalhadores das artes, trabalhadores da luta.) Fazendo-se tigre, o Coletivo Alfenim esgueira seus dentes sobre realidades que muitas das mais finas lâminas não alcançariam. Fazendo-se tigre, o Coletivo exercita em $O$ Deus da Fortuna diferentes estratégias de encontro com o "humano". $\mathrm{O}$ (des)encontro com o deus é uma delas, mas duas outras me parecem especialmente afiadas e maleáveis: o tigre e o sexo.

\section{GARRAS QUE SE EXPANDEM E RETRAEM}

A segunda estratégia, a que me referi anteriormente como sendo "o tigre", consiste na complexidade com que $O$ Deus da Fortuna arquiteta as relações de poder que perfazem o "humano" com que o Coletivo de Teatro Alfenim se compromete. Essa complexidade afasta do espetáculo, a priori, a identificação dos trabalhadores com posições estanques de subalternização, ingenuidade, inação ou passividade. Somente um olhar bastante descuidado para o espetáculo poderia levar à conclusão de que "os sonos profundos de inconsciência de classe" anunciados pelas personagens da trama - os mesmos sonos que garantem a absolvição do proprietário de terras implicariam num engessamento dos sujeitos subalternizados. Em verdade, de uma cena a outra da peça, os "subalternos" expandem e retraem suas garras de diversas formas, inclusive nos instantes cênicos em que os conflitos de classe são desenhados o mais didaticamente possível, como ocorre na cena em que os colonos se apresentam às portas da casa do Senhor Wang em busca do pagamento das provisões.

Embora o Secretário Koo tente convencer o Senhor Wang da necessidade de negociar com os colonos, embora recorde que um patrão que não honra a palavra perde a autoridade, o proprietário não cede. Anuncia que "este mês não terão regalias" e manda "surrar a cabeça da insurreição" visto que "os outros subirão as paredes

I5 BENJAMIN, Walter. O Autor como Produtor: Conferência Pronunciada no Instituto para o Estudo do Fascismo, em 27 de abril de I934. In: . Magia e Técnica, Arte e Política: Ensaios sobre Literatura e História da Cultura. Obras Escolhidas, v. I. Trad. de Sérgio Paulo Rouanet. 7. ed., II. reimpr. São Paulo, Brasiliense, 20II, p. I27.

I6 Idem, ibidem. 
como carrapatos". Mas os trabalhadores, em coro, não demoram a chegar à porta da casa do Senhor Wang. O Secretário Koo o avisa que os colonos solicitam uma audiência. Em cena, o coro se agiganta: "—Ei, velho sovina, apareça, você nos deve uma explicação"; "— Onde estão nossas provisões? Não vivemos de brisa"; "— As barcaças não saem sem nosso pagamento". O proprietário pergunta ao Secretário Koo o que os colonos estão dizendo. O Secretário se esgueira, constrange-se e tenta dissimular o conflito: "- Que pensam no senhor, a todo momento". Raivoso, o Senhor Wang retruca: "Não receberam as provisões? Que vão lamber o cu das vacas". Seguidas vezes, os trabalhadores reagem, o Secretário se esforça para o apaziguamento, o patrão se reafirma, até que os colonos crescem e gritam que queimarão toda a propriedade. "—Esses imbecis estão me ameaçando?" "— Não, Senhor Wang, eles dizem que queimarão incenso por sua piedade." O Senhor Wang se movimenta em direção aos colonos e emerge na sacada. Frente ao proprietário, os trabalhadores se ajoelham em reverência. O proprietário interroga, dura e disciplinadoramente: “- A quem pertence a terra que vocês pisam?”; “- A quem pertence as casas em que vocês moram?"; "-A quem pertence as sementes que vocês plantam?”. Em cena, entre uma pergunta e outra, os trabalhadores se olham silenciosos. "- Voltem para suas malocas, bando de imprestáveis. Vão chorar as pitangas ao Deus da Fortuna.” Os colonos se vão.

Uma primeira reação analítica a esta cena nos conduziria muito facilmente à noção de "ideologia", inclusive em seus empregos mais esquemáticos. Em linhas gerais, a cena acabaria por representar um arquétipo da "dominação de classe", da "falsa consciência" ou do "ocultamento da realidade" de que seriam vítimas os trabalhadores e de que decorrem sua subserviência e a consequente desistência do enfrentamento direto ao Senhor Wang. Entretanto, uma segunda reação analítica, mais densamente voltada para os meandros dramáticos da cena e para as altercações entre suas personagens, descortinaria relações de poder mais complexas do que o emprego esquemático do conceito de ideologia conseguiria comportar. Longe de desconhecerem, falseados, os impactos de suas ações frente ao seu senhor, os colonos conhecem habilidosamente os efeitos de sua organização e de sua tomada de decisão em "cruzar os braços". Eles perfilham, afinal, a importância de seu trabalho, de sua experiência e de sua existência. Eles se encontram em luta, gritam às portas da casa senhorial, xingam o proprietário, fazem-se ouvir e reconhecer ante a sua presença, ainda que a imagem do Senhor Wang lhes faça recuar e voltar às suas malocas. Por sua vez, o Senhor Wang, vencedor aparente do conflito, constrange-se raivoso e impaciente na sala de sua própria casa; passa recados através do Secretário Koo; finge não ouvir os gritos e xingamentos proferidos pelos colonos; irrita-se com as "traduções" desempenhadas pelo secretário até que, na extremidade do contexto, direciona-se para a varanda da casa e interroga os trabalhadores acerca dos limites da sua propriedade e, portanto, da "humanidade" dos insurretos. Na varanda, o proprietário associa aos bens senhoriais os verbos que os colonos conjugam - pisar, morar, plantar - e que, em conjugação, fazem deles sujeitos, supõem "trabalho". Mas a premência desse gesto de restauração de uma autoridade incontestável denuncia flagrantemente a contestabilidade dessa autoridade e a fragilidade com que ela se mantém entre ameaças de trabalhadores revoltosos e pressões de agiotas divinais. 
Em meio a colonos e proprietário, porém, a personagem do Secretário Koo talvez seja a que melhor concentre a segunda das estratégias acima enumeradas. $\mathrm{Na}$ qualidade de secretário, Koo é um empregado mais próximo do Senhor Wang. Suas falas durante o espetáculo demonstram seu conhecimento dos problemas econômicos atravessados pelo patrão e seus vínculos mais estreitos com ele. A despeito dessas distinções, o Secretário Koo permanece sendo um empregado e, como tal, encontra-se numa relação explícita de subordinação. Isto não impede, todavia, que o secretário promova as "traduções" - de intenção apaziguadora - entre os colonos e o Senhor Wang, assim como não impossibilita que ele, num jogo cênico que me parece ser um dos melhores momentos do espetáculo, dê uma surra no patrão. Acontece mais ou menos assim: ao receber a notícia de que os colonos haviam paralisado seus trabalhos, o Senhor Wang, que bebia vinho desde que chegara do encontro com o Mestre Cai Fu em que negociaram o casamento dos seus filhos, já se encontrava alcoolizado. Muito irritado, o Senhor Wang manda surrar a cabeça da insurreição. O Secretário Koo, ao seu tempo, alerta, como dito anteriormente, que um patrão que não honra a sua palavra perde a autoridade. O proprietário não retrocede sua posição e dá novas ordens ao secretário. Mas em certo momento, o Senhor Wang, talvez tomado pelo vinho, acredita ter visto o Deus da Fortuna no meio da sala. Determina então que o Secretário Koo use um bastão para acertar o deus. O secretário ergue o bastão e tenta uma, duas, três vezes acertar o deus imaginário. Não conseguindo cumprir com os mandos e desmandos fantasmagóricos do Senhor Wang, Koo resolve entrar na brincadeira.

Secretário Koo: - Agora eu vejo, Senhor Wang! Ele entrou nas suas vestes. (Suspensão. Koo espreita. Wang congela. Koo indica algo às costas de Wang, que acena tentando dialogar por sinais. Num átimo, o Secretário cai de pau sobre o patrão.)

Secretário Koo (enquanto desfere bastonadas em Wang): — Biltre! Canalha! Patife! Salafrário! Sacripanta! Vigarista! Covarde! Facínora! Mentecapto!

Senhor Wang: — Pare!!!

A hilária (e irônica) surra desferida pelo Secretário Koo no patriarca Senhor Wang provoca risadas maravilhadas na plateia. Mas, além disso, aponta para a sagacidade do Coletivo Alfenim na exploração do conceito de "contradição". Inegavelmente, deus e tigre constituem uma "unidade de contrários". No entanto, num corte analítico próximo ao que Walter Benjamin procedeu ante a vingança do ator, o Coletivo enfrenta diferentes mediações do conceito de contradição. Articula inclusive a brevidade do espaço-tempo em que, tal qual o ator triunfa, o tigre mostra e recolhe suas garras e seus dentes. Ora, se as contradições alimentam a feitura da história, esta história é repleta de complexas táticas de ação dos "subordinados" e de desequilíbrio das relações de poder. Em O Deus da Fortuna, a surra é um exemplo dessas táticas. Há outros. A personagem de Liu Po, a empregada mais nova da casa senhorial, aponta dois deles. 
Num diálogo com a filha, o Senhor Wang antecipa que ela deverá se casar com o filho de Cai Fu. Jin-Jing, então, contradiz: "— Mas... Por que devo me casar?". O pai responde, recorrendo ao “óbvio": "— Você me deve obediência!”. Impertinente, Liu Pu intervém na conversa, agora recorrendo a obviedades impronunciáveis: "E seu pai (deve obediência) a Mestre Cai Fu, o agiota". O patrão a expulsa da sala exaltado. Noutra cena, Jin-Jing e Liu Po conversam. A filha do patrão se ressente de não conhecer o amor. Em determinada altura da conversa, a moça acusa a empregada de não possuir ambição. Liu Po discorda: "—Claro que tenho. Um dia, os pobres como eu chutaremos a bunda dos ricos e a riqueza que produzimos será dividida entre todos". As duas dissentem e Jin-Jing conclui, posicionando-se superiormente: "— Não sei por que insisto em ter amizade por tipos como você". Liu Po explica: "— Você é a patroinha. Se você insiste, eu obedeço".

Esta segunda estratégia de encontro com o "humano" desenlaçada pelo Coletivo de Teatro Alfenim proporciona reflexões muito próximas àquelas desenvolvidas pelos setores do campo marxista menos preocupados com chaves explicativas dicotômicas entre "posições estruturais" ou "reproduções superestruturais" e mais atentos às historicidades, às movimentações dos sujeitos em conflito, às relações sociais e às experiências que oportunizam a performatização dos sujeitos. Estes são indivíduos e, reciprocamente, são classe. Sendo assim, a impertinência de Liu Po não se caracteriza como um ato solitário. Trata-se de uma impertinência de classe, de uma tática subterrânea que se replica em outras personagens do espetáculo, como o Secretário Koo, mas que dialoga intimamente com o levante organizado dos colonos. A percepção dessa trama de impertinências e táticas, entretanto, requer que nossos esforços analíticos se movimentem ao ritmo com que os sujeitos e conflitos se movimentam. Trata-se de algo metodologicamente parecido com o que Marx praticou em suas "Obras Históricas” ${ }^{17}$ ou com o que historiadores como E. P. Thompson ${ }^{\mathrm{I} 8}$ concluíram a respeito da necessidade de ir além dos pressupostos (já conclusivos em sua gênese) do "marxismo estruturalista": se "as estruturas" explicam essencialmente tudo, que sentido há seja nas ações e transgressões forjadas pelos sujeitos na tessitura da história, seja na atividade de um pesquisador diante de seu objeto de pesquisa, seja na práxis criativa de um coletivo teatral engajado nas lutas sociais? Bem, "as estruturas" - se é que elas de fato existem apartadas de tudo o mais, do que duvido - não conjugam verbos, não explicam essencialmente, como não pisam, não moram, não plantam coisa alguma, não dão surras no patrão, também não gritam ou xingam à sua porta.

Enfim, a terceira estratégia de encontro com o "humano" - a que eu chamei de "o sexo" - acionada pelo Coletivo de Teatro Alfenim aprofunda a complexificação das relações de poder a que me referi páginas atrás, mas agora investe nos entrecruzamentos constitutivos entre as relações de classe, gênero e sexualidade. Nesses entrecruzamentos, as relações sociais - de classe ou de gênero, de sexualidade

I7 Refiro-me, especialmente, a dois textos marxianos: MARX, Karl. As Lutas de Classes na França de I848 a I850. Trad. de Nélio Schneider. São Paulo, Boitempo, 20I2; .Manuscritos Econômico-filosóficos. Trad. de Jesus Ranieri. I. ed., 2. tiragem. São Paulo, Boitempo, 2006. I8 THOMPSON, E. P. Senhores e Caçadores. Trad. de Denise Bottmann. 2. ed. Rio de Janeiro, Paz e Terra, I997. 
ou territoriais - fazem-se umas às outras, não deixando margem para abordagens equacionais entre "centralidades" e "especificidades". Em outras palavras, a “centralidade do trabalho" cara à tradição marxista somente se torna possível analiticamente se esse mesmo trabalho é percebido, por exemplo, como forjado em relações de gênero e sexualidade, generificado e sexualizado, na constituição de sua experiência histórica. Não à toa, o Senhor Wang pretende que o casamento de sua filha sirva de artifício para a extinção de suas dívidas junto ao agiota. A virgindade da filha e a própria filha do proprietário são proprietarizadas. Se, como argumentei antes, a equiparação de Jin-Jing a um saco de batatas ou a uma dúzia de vacas emblematiza a relativização da sua "humanidade" e a fragilidade das fronteiras que distinguem humanos, animais ou coisas, ela nos permite apreender, dialeticamente, as relações de generificação e sexualização da propriedade, da terra. O rompimento negociado da virgindade da moça salva as terras do seu pai porque entre a gestão da sexualidade de Jin-Jing e a administração daquelas terras há cumplicidades históricas.

Em suas análises sobre as genealogias do imperialismo, Anne McClintock investiga tais cumplicidades entre os processos de territorialização, generificação e sexualização. Ela alude à "longa tradição de viagens masculinas como uma erótica do alumbramento" «و. Nessa erótica, reproduzir-se-iam gestos de penetração masculina sobre a evidenciação de um interior feminino velado, as "terras virgens" de que ouvimos falar com frequência. Haveria então um mundo feminizado a ser exposto e explorado por desbravadores masculinizados. As fronteiras desses mundos desconhecidos se fariam ameaçadoras e sedutoras, precisando ser domadas pelos autodenominados exploradores. Espaços fronteiriços, assim, não só seriam feminizados - para serem rompidos - como se concretizariam nos corpos das mulheres, "figuras mediadoras e liminares por meio das quais os homens se orientavam no espaço, como agentes do poder e do conhecimento" ${ }^{20}$. A literatura feminista tem indicado a crueldade com que essas concretizações se perfazem em contextos de disputas territoriais ${ }^{21}$.

Contudo, longe de conduzirem à conclusão de que há, aí, um exemplo de "patriarcado" - compreendido como estrutura universal que se multiplica em realidades distintas - desses conflitos de gênero e sexualidade se depreendem disputas cortantes acerca de masculinizações e femininizações. "Pai" ou "pater", por exemplo, não são categorias óbvias ou dados estruturais. São performances de gênero sob conflito, um conflito que é, assim, de gênero, sexualidade, classe e territorial reciprocamente. E $O$ Deus da Fortuna oferece inúmeras oportunidades para a análise

I9 McCLINTOCK, Anne. Couro Imperial: Raça, Gênero e Sexualidade no Embate Colonial. Trad. de Plínio Dentzien. Campinas, Unicamp, 20Io, p. 43.

20 Idem, p. 48.

2I Os trabalhos de Andréa Péres sobre os “campos de estupro" de mulheres na guerra da Bósnia e os de Rita Laura Segato sobre os assassinatos de mulheres em Ciudad Juarez são importantes exemplos dessa literatura. Ver, por exemplo: PÉRES, Andréa Carolina Schvartz. Campos de Estupro: as Mulheres e a Guerra na Bósnia. Cadernos Pagu, n. 37, Campinas, 20II, p. II7-I62; SEGATO, Rita Laura. Território, Soberania e Crimes de Segundo Estado: a Escritura nos Corpos das Mulheres de Ciudad Juarez. Estudos Feministas, Florianópolis, v. I3, n. 2, 2005, p. 265-285. 
dessas performances e dos conflitos que as subjazem. Na cena em que o Senhor Wang vai ao encontro do Mestre Cai Fu com o objetivo de "penhorar as virtudes de sua filha", a personagem do proprietário corporifica esses conflitos e demonstra as fragilidades com que se sustenta a autoridade masculina normativamente inquebrantável do grande pai.

Desolado com as palavras de Cai Fu e com a notícia de que o agiota não poderia lhe conceder um novo empréstimo, o Senhor Wang pergunta ao Mestre o que poderia fazer. Cai Fu sequer pestaneja. Chama seu filho Shang à presença do Senhor Wang e anuncia que o proprietário quer lhe fazer "um agrado". O Senhor Wang então sugere: "- O menino Shang gosta de cavalos, não é verdade? Tenho belos corcéis em minha propriedade. Podemos ir agora mesmo". Mas Mestre Cai Fu tem outra ideia de "agrado": "— Não é necessário. Meu filho adora brincar". Diante do agiota e do futuro esposo de sua filha, o Senhor Wang se ajoelha. Num chiste retórico mordaz, Cai Fu ordena ao filho: "- Pode montar, meu filho. É um excelente animal. Use o chicote. Veja como galopa feliz pelos vales, cavalgue pelas pradarias, suba as montanhas, observe o horizonte, não dê trégua, esporeie, esfole, o animal lhe pertence, você é o senhor!”. Depois de um tempo, o Senhor Wang se desvencilha do rapaz e, recompondo-se, elogia: "- Mestre Cai Fu, seu filho Shang é um excelente cavaleiro. Jin-Jing, minha filha, se sentirá honrada em empenhar sua virtude". O casamento é negociado.

A cena de suposta humilhação do patriarca consiste, sem dúvida, numa metáfora sexual. Em cena, os atores tornam os prazeres implicados na submissão (de quatro) do senhor ainda mais evidentes. Há desejo nas entrelinhas e sobre elas. E esse desejo exibe fetiches que intersectam imagens de sexualidade a outras relações de poder. O pater se constrange, animaliza-se, o rapaz se compraz em seu lombo, provoca-lhe dor. A cena lembra as teatralizações sadomasoquistas ${ }^{22}$, as "brincadeiras" entre os meninos da "Casa-grande" e os meninos da senzala, de que falou Gilberto Freyre ${ }^{23}$, e diversas outras relações de poder encenadas através de ritualizações sexuais. Mostra ademais o esforço colossal e sexual de manutenção dos signos patriarcais ${ }^{24}$. Para manter as suas terras, o Senhor Wang não somente vende sua filha como venderia "uma boa dúzia de vacas", mas antes de completar a negociação do casamento de Jin-Jing, dispõe o seu próprio corpo como arena para o exercício de masculinizações. Ao final da cavalgada, a "virilidade" de

22 Nas narrativas das "comunidades" que identificam suas experiências como "sadomasoquistas", entretanto, o "consentimento" é um elemento central, contrário inclusive ao exercício da violência. A esse respeito, sugiro a leitura de: FACCHINI, Regina \& MACHADO, Sarah Rossetti. "Praticamos SM, Repudiamos Agressão": Classificações, Redes e Organização Comunitária em Torno do BDSM no Contexto Brasileiro. Sexualidad, Salud y Sociedad - Revista Latinoamericana, Rio de Janeiro, n. I4, 20I3, p. I95-228. Disponível em: 〈http://goo.gl/7hwaEE〉. Data de acesso: I8 jan. 2015.

23 FREYRE, Gilberto. Casa-grande e Senzala: Formação da Família Brasileira Sob o Regime da Economia Patriarcal. 5I. ed. São Paulo, Global, 2006.

24 Para uma excelente crítica a apreensões normativas da noção de "família patriarcal”, ver: CORRÊA, Mariza. Repensando a Família Patriarcal Brasileira: Notas para o Estudo das Formas de Organização Familiar do Brasil. Cad. Pesq., São Paulo, n. 37, I98I, p. 5-I6. 
Shang, contestada em alguns momentos do espetáculo, resta aparentemente comprovada - a dependência de Wang a Cai Fu, também.

Se o espetáculo exibe meandros, reentrâncias e melindres da "autoridade masculina” e, sendo assim, contesta quaisquer simplificações analíticas acerca das relações de gênero e sexualidade, seu tratamento das "mulheres" não poderia deslizar para "vitimismos" Wang, personifica um emblema de gênero da proprietarização e da animalização do feminino. Ela é negociada em casamento, vale "vacas". As empregadas da casa servem à iniciação ou à satisfação sexual do seu senhor. A Senhora Wang, aparentemente triste num casamento arranjado com o Senhor Wang, suicida-se, afoga-se no lago da propriedade. Todavia, o peso desses constrangimentos e relações de subordinação não implica na passivização das personagens femininas. O Deus da Fortuna demonstra que também nos interstícios de relações coagidas de gênero e sexualidade, o "humano" e suas impertinências se mobilizam. Basta ouvir o que as mulheres dizem quando os homens se ausentam.

$\mathrm{Na}$ cozinha da casa senhorial, durante o preparo do pato para o banquete do casamento daquela noite, uma conversa entre mulheres se desenlaça. Jin-Jing lamenta pelo casamento e insiste na ideia de suicídio. Matar-se-ia como um dia fez sua mãe. Mas a Senhora Shu, a empregada mais velha, enquanto orienta Liu Po a estripar o pato, esforça-se para dissuadir a moça daquela ideia. "- Jin-Jing, você deve acatar a decisão do Senhor Wang. Nesta casa, a melhor forma de desobedecer é sempre estar de acordo". A partir daí, entre o desespero da moça e os temperos que penetram os orifícios inferiores e superiores do pato, a conversa se transforma numa pedagogia de táticas e impertinências de gênero e sexualidade. A Senhora Shu rememora - e, portanto, reconstrói - a história do suicídio da mãe de Jin-Jing. "—É preciso estar de acordo: ensinei essa lição à sua mãe. Com o tempo, ela aprendeu a lidar com o Senhor Wang. Quando percebeu que era inútil protestar, passou a confrontar a tirania do marido sempre com um sorriso nos lábios." Segundo a Senhora Shu, o pai de Jin-Jing, diante da amabilidade da esposa, parou de esbravejar. A Senhora Wang, por sua vez, passou a buscar novos prazeres. "- Depois disso, a Senhora Wang começou a agir de acordo com o que acreditava; ia ao mercado de sedas toda enfeitada. Às vezes, voltava só depois de três dias, muda, feliz e cheirando a doce vinho. Quando seu pai percebeu, era tarde. Ele a perdeu e nem pôde reclamar." Curiosa com a história tecida pela Senhora Shu, Jin-Jing então pergunta sobre o porquê de sua mãe ter se jogado no lago. "- Dizem que foi de tristeza, mas não, foi por amor de alguém que nunca saberemos." A Senhora Shu morreu por amor.

Tais táticas e impertinências de gênero e sexualidade não destronam o "patriarca" tampouco obstam os processos de proprietarização e animalização das mulheres. Pouco antes do banquete, o Senhor Wang questiona a Senhora Shu se Jin-Jing está pronta para o casamento. A velha empregada responde: "-Como um pato selvagem na mira do caçador". Táticas e impertinências, no entanto, cambaleiam a rigidez das relações de subordinação e lembram a todo tempo que aqueles processos são

25 GREGORI, Maria Filomena. As Desventuras do Vitimismo. Revista Estudos Feministas, Florianópolis, n. I, I993, p. I43-I49. 
“processos”, ou seja, não correspondem a “dados”. Os processos de proprietarização das mulheres, por exemplo, não engendram mulheres-propriedade tão facilmente. Essas mulheres, como o tigre, conjugam seus verbos, estripam patos, amam e bebem vinho clandestinamente e, se morrem, também lutam. Jin-Jing teima perante as empregadas: "- O melhor a fazer é cortar os pulsos e repousar docemente à espera da morte". A Senhora Shu sentencia: "- Existem boas formas de morrer, mas a mais honesta é lutando". Esta terceira estratégia de encontro com o "humano" talvez seja a que melhor ratifica a maleabilidade com a que o Coletivo de Teatro Alfenim desvenda e disputa a realidade que nos cerca. Não apenas a quarta parede do palco é derrubada. As quatro paredes do "quarto de casal" o são. Também as do "quarto da empregada". E, inclusive, as da "sala de estar", onde o sexo é negociado. Aqui, como em todo o espetáculo, o Coletivo de Teatro Alfenim se supera. Aqui, ele nos corta maleável e afiadamente.

\section{SOBRE O AUTOR}

ROBERTO EFREM FILHO professor do Departamento de Ciências Jurídicas da Universidade Federal da Paraíba e doutorando em Ciências Sociais junto ao Instituto de Filosofia e Ciências Humanas da Universidade Estadual de Campinas.

E-mail: robertoefremfilho@gmail.com

\section{REFERÊNCIAS BIBLIOGRÁFICAS}

ADORNO, Theodor. Indústria Cultural e Sociedade. Seleção de textos: Jorge Mattos Brito de Almeida. Trad. de Julia Elisabeth Levy, Jorge Mattos Brito de Almeida e Maria Helena Ruschel. 3. ed. São Paulo, Paz e Terra, 2006.

BENJAMIN, Walter. Magia e Técnica, Arte e Política: Ensaios sobre Literatura e História da Cultura. Obras Escolhidas, v. I. Trad. de Sérgio Paulo Rouanet. 7. ed., II. reimpr. São Paulo, Brasiliense, 2 OII.

COLETIVO Alfenim. O Deus da Fortuna, 20I4. Mimeo.

CORRÊA, Mariza. Repensando a Família Patriarcal Brasileira: Notas para o Estudo das Formas de Organização Familiar do Brasil. Cad. Pesq., São Paulo, n. 37, I98I, p. 5-I6.

FACCHINI, Regina \& MACHADO, Sarah Rossetti. “Praticamos SM, Repudiamos Agressão”: Classificações, Redes e Organização Comunitária em Torno do BDSM no Contexto Brasileiro. Sexualidad, Salud y Sociedad - Revista Latinoamericana, Rio de Janeiro, n. I4, 2013, p. I95-228. Disponível em: 〈DOI:Io.I590/sI984-648720I30002000I4〉. Data de acesso: I8 jan. 2015.

FREIRE, Paulo. Pedagogia do Oprimido. 36. ed. São Paulo, Paz e Terra, 2003.

FREYRE, Gilberto. Casa-grande er Senzala: Formação da Família Brasileira Sob o Regime da Economia Patriarcal. 5I. ed. São Paulo, Global, 2006. 
GREGORI, Maria Filomena. As Desventuras do Vitimismo. Revista Estudos Feministas, Florianópolis, n. I, I993, p. I43-I49.

JAMESON, Fredric. A Virada Cultural: Reflexões sobre o Pós-moderno. Trad. de Carolina Araújo. Rio de Janeiro, Civilização Brasileira, 2006.

MARX, Karl. As Lutas de Classes na França de I848 a I850. Trad. de Nélio Schneider. São Paulo, Boitempo, 2012

. Manuscritos Econômico-filosóficos. Trad. de Jesus Ranieri. I. ed., 2. tiragem. São Paulo, Boitempo, 2006.

McCLINTOCK, Anne. Couro Imperial: Raça, Gênero e Sexualidade no Embate Colonial. Trad. de Plínio Dentzien. Campinas, Unicamp, 2010.

PÉRES, Andréa Carolina Schvartz. Campos de Estupro: as Mulheres e a Guerra na Bósnia. Cadernos Pagu, n. 37, Campinas, 20II, p. II7-I62. Disponível em: 〈http://goo.gl/IRfFMH〉. Acesso em: I8 jan. 2015.

RANGEL, Flávio \& FERNANDES, Millôr. Liberdade, Liberdade. 5. ed. São Paulo, L\&PM, I987.

SEGATO, Rita Laura. Território, Soberania e Crimes de Segundo Estado: a Escritura nos Corpos das Mulheres de Ciudad Juarez. Estudos Feministas, Florianópolis, v. I3, n. 2, 2005, p. 265-285. Disponível em: <DOI:IO.I590/s0I04-026x2005000200003〉. Acesso em: I8 jan. 2015.

THOMPSON, E. P. Senhores e Caçadores. Trad. de Denise Bottmann. 2. ed. Rio de Janeiro, Paz e Terra, I997. 